\title{
PERSPEKTIF BIMBINGAN KONSELING DALAM PENDIDIKAN ISLAM
}

\author{
Galuh Nashrullah Kartika MR \\ Email: ganash_kamasaro@yahoo.com \\ Dosen FAI UNISKA Banjarmasin \\ Jalan Adyaksa No 2 Banjarmasin
}

\begin{abstract}
Guidance is the assistance given to students to have the potential possessed optimally developed by understanding themselves, the environment, overcoming obstacles in order to determine the future plan better. In other words, guidance is the process of providing help done by someone who is an expert to someone or some individual individual, whether children, adolescents, or adults, so that the guided person can develop selfsufficiency and self-sufficiency by utilizing the power of individuals and the means existing and can be developed based on prevailing norms, so guidance is also held in order to help each individu to better recognize various information about himself. Counseling is a face-to-face personal relationship between two people where the counselor through the relationship with his special abilities, provides a learning situation. In this case counseling is helped to understand oneself, current circumstances, and possible future circumstances that he can create by using his potential, for the sake of personal and community well-being. Further counseling can solve problems and find future needs.
\end{abstract}

Keywords: Counseling Guidance, Islamic Education, Individual

\section{PENDAHULUAN}

Berdasarkan pendapat ahli jiwa, bahwa yang mengendalikan tindakan seseorang adalah kepribadiannya. Kepribadian terbentuk dari pengalaman-pengalaman yang telah dilaluinya. Untuk itulah perlu adanya bimbingan dan pengajaran serta penanaman nilai-nilai agama Islam dan pembiasaan-pembiasaan yang baik sejak lahir. Hal tersebut dimaksudkan agar dapat membentuk kepribadian manusia yang berakhlak karimah yang sesuai dengan ajaran agama. ${ }^{1}$

Islam merupakan sumber utama dalam membentuk pribadi seorang muslim. Dengan berlandaskan Al-Qur'an dan Al-Sunnah, Islam mengarahkan dan membimbing manusia ke jalan yang diridhai-Nya dengan membentuk kepribadian yang berakhlak karimah. Sebagaimana sabda Rasulullah SAW:

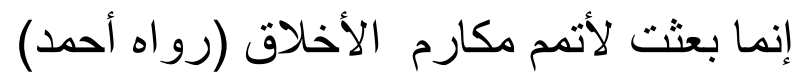

"Sesungguhnya aku diutus untuk menyempurnakan akhlak yang mulia."

Nabi diutus oleh Allah SWT untuk membimbing dan mengarahkan manusia ke arah kebaikan yang hakiki dan juga sebagai figur konselor yang sangat mumpuni dalam memecahkan berbagai permasalahan yang berkaitan dengan jiwa manusia agar manusia terhindar dari segala sifat-sifat yang negatif. Oleh karena itu, manusia diharapkan dapat saling memberikan bimbingan sesuai dengan kapasitasnya, sekaligus memberikan konseling agar

\footnotetext{
${ }^{1}$ Abdul Hayat. 2008. Konsep K onseling Berdasarkan Ayat-ayat Al-Quran. Banjarmasin: Antasari Press
} 
tetap sabar dan tawakal dalam menghadapi perjalanan kehidupan yang sebenarnya. Dengan pendekatan Islam, maka pelaksanaan konseling akan mengarahkan klien ke arah kebenaran, membimbing dan mengarahkan hati, akal dan nafsu manusia menuju kepribadian yang berakhlak karimah sesuai nilai-nilai Islam. ${ }^{2}$ Dalam hal ini perlu diperhatikan oleh konselor untuk menunjang kesuksesan pendidikan Islam di sekolah maupun madrasah dalam melaksanakan bimbingan dan konseling agar mengentaskan berbagai permasalahan yang dihadapi oleh peserta didik serta mengarahkannya untuk membentuk manusia yang memiliki kepribadian berakhlak karimah.

Tulisan sederhana yang ada di tangan pembaca ini akan membahas tentang Linkcage antara bimbingan konseling dan pendidikan Islam, strategi dalam bimbingan dan konseling Islam, perluasan setting bimbingan dan konseling.

\section{HASIL PEMBAHASAN}

\section{Linkcage Antara Bimbingan Konseling dan Pendidikan Islam}

\section{a. Pengertian Bimbingan Konseling}

Bimbingan dan konseling merupakan alih bahasa dari istilah Inggris guidance dan counseling. Dalam kamus bahasa Inggris "guidance" dikaitkan dengan kata asal guide, yang diartikan sebagai berikut; menunjukkan jalan (Showing the way), memimpin (leading); menuntun (conducting); memberikan petunjuk (giving instruction); mengatur (regulating); mengarahkan (governing); memberikan nasehat (giving advice). ${ }^{3}$

Adapun pengertian bimbingan menurut Jones dalam Bimo Walgito adalah Guidance is the assistance given to individuals in making intelligent choices and adjustments in their lives. The ability is not innate it must be developed. The fundamental purpose is to develop in each individual up to the limit of capacity, the ability to solve his own problems and to make his own adjustment. ${ }^{4}$

Sementara Chisholm dalam Bimo Walgito memberikan pengertian mengenai bimbingan dengan sedikit lebih luas yaitu, "guidance seeks to have each individual become familiar with a wide range of information about himself, his abilities, his previous development in the various areas of living, and his plans or ambitions for the future. Guidance than seeks to help him become acquanted with the various problems of social, vocational and recreational adjustment with he faces. On the basis of those two types of information and the assistance of counselors, each pupil is helped to face his problems and makes plans for their solution. Secara sederhana dari kedua pengertian tersebut dapat dikatakan bahwa bimbingan adalah "a process of helping an individual to understand himself and his world" proses pemberian bantuan kepada individu agar mampu memahami diri dan lingkungannya.

Sebagaimana Bimo Walgito mendefinisikan bahwa bimbingan adalah bantuan atau pertolongan yang diberikan kepada individu atau sekumpulan individu dalam menghindari atau mengatasi kesulitan-kesulitan hidupnya, agar individu dapat mencapai kesejahteraan dan kebahagiaan dalam kehidupannya.

\footnotetext{
${ }^{2}$ Samsul Munir dan Amin. Bimbingan Konseling Islam. Jakarta: Amzah

${ }^{3}$ Ngalimun. 2013. Pelaksanaan Layanan Bimbingan Konseling di SD/MI. Yogyakarta: Deppublish

${ }^{4}$ Bimo Walgito. 2005. Bimbingan dan Konseling (studi dan karier). Yogyakarta: Andi Offset
} 
Meski dalam mendefinisikan istilah bimbingan tersebut para ahli bidang bimbingan konseling memberikan pengertian yang berbeda-beda, pengertian yang mereka sajikan memiliki satu kesamaan arti bahwa bimbingan merupakan suatu proses pemberian bantuan.

Dalam kamus bahasa Inggris, counseling dikaitkan dengan kata counsel, yang diartikan sebagai berikut; nasehat (to obtain counsel); anjuran (to give counsel); pembicaraan (to take counsel). dengan demikian, counseling dapat diartikan sebagai pemberian nasehat; pemberian anjuran; dan pembicaraan dengan bertukar pikiran.

Mengenai konseling, Jones dalam Walgito memberikan pengertian sebagai berikut; "Counseling is talking over a problem with some one. Usually but not always, one of the two has facts or experiences or abilities not possessed to the same degree by the other. The process of counseling involves a clearing up of the problem by discussion." Sedangkan Wren menekankan pada hubungan personal yang saling menguntungkan; "Counseling is personal and dynamic relationship between to people who approach a mutually defined problem with mutual consideration for each other to end that the younger, or more troubled of the two is aided to a self determined resolution of his problem."

Mengenai kedudukan dan hubungan antara bimbingan dan konseling terdapat banyak pandangan, salah satunya memandang bahwa konseling sebagai teknik bimbingan, dengan kata lain konseling berada dalam bimbingan. Pendapat lain menyatakan bahwa bimbingan merupakan pencegahan munculnya masalah yang dialami oleh individu dengan kata lain bimbingan sifat atau fungsinya preventif (pencegahan), sedangkan konseling sifatnya kuratif dan korektif. Namun bimbingan dan konseling dihadapkan pada objek yang sama yaitu problem sedangkan perbedaannya terletak pada perhatian dan perlakuan dari masalah.

Konseling merupakan suatu hubungan profesional antara seorang konselor yang terlatih dengan klien. Hubungan ini biasanya bersifat individual, meskipun kadangkadang melibatkan lebih dari dua orang dan dirancang untuk membantu klien memahami dan memperjelas pandangan terhadap ruang lingkup hidupnya, sehingga dapat membuat pilihan yang bermakna bagi dirinya. ${ }^{5}$

Setelah menyimak pendapat di atas dapat disimpulkan bahwa bimbingan konseling adalah proses pemberian bantuan yang dilakukan melalui wawancara konseling (face to face) oleh seorang ahli (konselor) kepada individu yang sedang mengalami sesuatu masalah (konseli) yang bermuara pada teratasinya masalah yang dihadapi konseli serta dapat memanfaatkan berbagai potensi yang dimiliki dan sarana yang ada, sehingga individu atau kelompok individu itu dapat memahami dirinya sendiri untuk mencapai perkembangan yang optimal, mandiri serta dapat merencanakan masa depan yang lebih baik untuk mencapai kesejahteraan dan kebahagiaan hidup.

\section{b. Pendidikan Islam}

Kata Pendidikan sinonim dengan kata Tarbiyah dalam bahasa Arab. Pendidikan Islam mengarahkan manusia kepada kehidupan yang lebih baik, mengangkat derajat

\footnotetext{
${ }^{5}$ Tohari, Musnawar. 2010. Dasar-dasar Konseptual Bimbingan Konseling Islam. Yogyakarta: UII Press
} 
kemanusiaannya sesuai fitrah dan mengoptimalkan kemampuannya untuk merespon pengaruh dari luar secara tepat sesuai tuntunan al-Qur'an dan al-Sunnah. ${ }^{6}$

Adapun tujuan pendidikan Islam adalah sebagai berikut:

1) Untuk mengembangkan fitrah dan memberikan kemampuan pada peserta didik agar dapat memimpin hidupnya sesuai dengan cita-cita hidup Islam, semaksimal mungkin.

2) Untuk mewariskan dan mengembangkan budaya dalam rangka membentuk corak kepribadian muslim sesuai dengan prinsip-prinsip dan nilai-nilai Islam serta kondisi sosial, budaya, ekonomi, dan politik umat Islam.

3) Untuk menyeimbangkan seluruh aspek kehidupan manusia baik spiritual, intelektual, imajinasi, jasmaniah, bahasa, baik individu maupun kelompok dan mendorong aspek-aspek itu ke arah kebaikan dan pencapaian kesempurnaan hidup.

4) Untuk mengembangkan berpikir bebas dan mandiri agar dapat membentuk manusia yang berguna bagi alam dan sesamanya (insan kamil).

Tujuan pendidikan Islam bukan hanya untuk memahami ajaran Islam, namun juga untuk mengamalkan ajaran-ajaran tersebut dalam kehidupan sehari-hari. Pendidikan Islam sebagaimana tersebut di atas masih memiliki berbagai kelemahan, seperti belum bisa berfungsi sebagai pengendali moral dan akhlak bangsa, di beberapa sekolah masih terdapat sistem belajar-mengajar yang monoton, bimbingan konseling belum melembaga secara baik. Sedangkan dilihat dari sisi individu sebagai peserta didik, problem pendidikan diidentifikasi antara lain sebagai berikut; ${ }^{7}$

1) Individu tidak terampil mengerjakan sesuatu yang seharusnya bisa dilakukan setelah mempelajari.

2) Individu tidak juga bisa memahami pokok bahasan (materi pelajaran) meski telah dicoba mempelajarinya sekuat tenaga.

3) Individu segan atau malas untuk mempelajari bahan pelajaran tertentu.

4) Individu sulit menyelesaikan tugas-tugas sekolah karena di rumah terlalu banyak pekerjaan yang juga harus diselesaikan.

5) Individu berkali-kali gagal menguasai bahan pelajaran yang harus dipelajarinya sesuai dengan target yang seharusnya.

Maju mundurnya sebuah institusi pendidikan dipengaruhi oleh beberapa faktor, di antaranya adalah:

1) Faktor intern, meliputi (a) Kecerdasan, yaitu kemampuan untuk memahami dan menghadapi situasi dan kondisi sekitar dengan cepat. (b) Bakat, yaitu potensi atau kemampuan terpendam yang sangat menonjol di dalam bidang tertentu. (c) Minat, yaitu kemauan, kehendak atau hasrat yang kuat terhadap sesuatu. (d) Perhatian, yaitu dorongan untuk mencurahkan daya kemampuan pengamatan (dengan panca indera terhadap sesuatu). (e) Keadaan mental (psikis), yakni keadaan senang, sedih,

\footnotetext{
${ }^{6}$ Lubis dan Saiful Akhyar. 2007. Konseling Islami: Kyai dan Pesantren. Yogyakarta: Elak Press

${ }^{7}$ Daud Wan Muhammad Nor Wan. 1998. Filsafat dan Praktik Pendidikan Islam. Bandung: Mizan
} 
gembira, duka, gelisah, dan sebagainya. (f) Keadaan fisik, yakni fisik dalam keadaan sehat atau sakit.

2) Faktor ekstern, meliputi (a) Bahan/materi yang dipelajari. (b) Situasi dan kondisi fisik. (c) Situasi dan kondisi lingkungan. (d) Sistem pendidikan/pengajaran.

\section{c. Bimbingan Konseling dan Pendidikan Islam}

Secara rinci linkcage bimbingan konseling dan pendidikan Islam adalah sebagai berikut: ${ }^{8}$

1) Membantu individu mencegah timbulnya problem-problem yang berkaitan dengan kegiatan belajar/pendidikan antara lain, (a) Membantu individu memahami hakikat pendidikan Islam. (b) Membantu individu memahami tujuan dan kedudukan pendidikan menurut Islam. (c) Membantu individu memahami faktor-faktor yang mempengaruhi keberhasilan belajar. (d) Membantu individu menyiasati kegiatan belajar agar berhasil. (e) Membantu individu melakukan kegiatan belajar sesuai dengan ketentuan syariat Islam.

2) Membantu individu memecahkan masalah-masalah yang berkaitan dengan belajar/pendidikan antara lain, (a) Membantu individu agar mampu memahami problem yang dihadapinya. (b) Membantu individu memahami kondisi dirinya dan lingkungannya. (c) Membantu individu memahami dan menghayati cara-cara mengatasi masalah belajar yang sesuai dengan ajaran Islam. (d) Membantu individu menetapkan pilihan dalam usaha memecahkan masalah yang dihadapi sesuai dengan ajaran Islam.

3) Membantu individu memelihara situasi dan kondisi kegiatan belajar agar tetap baik dan mengembangkannya menjadi lebih baik antara lain, (a) Memelihara individu yang situasi dan kondisi belajarnya yang bermasalah telah teratasi, tidak kembali bermasalah. (b) Mengembangkan situasi dan kondisi belajar menjadi lebih baik.

Lebih jauh linkcage antara bimbingan konseling dengan pendidikan Islam adalah hubungan yang tak terpisahkan, bagai dua wajah dalam sekeping mata uang. Keduanya saling melengkapi dan menyempurnakan.

\section{Strategi Bimbingan dan Konseling Islam}

\section{a. Pengertian Bimbingan dan Konseling Islam}

Ada beberapa defenisi tentang bimbingan dan konseling Islam, yaitu: ${ }^{9}$

1) Tohirin mengartikan bimbingan dan konseling Islam sebagai suatu proses pemberian bantuan terhadap individu agar menyadari kembali eksistensinya sebagai makhluk Allah SWT yang seharusnya hidup selaras dengan ketentuan dan petunjuk Allah SWT, sehingga dapat mencapai kebahagiaan dunia dan akhirat.

2) Bimbingan dan konseling agama Islam adalah pelayanan bantuan yang diberikan oleh konselor agama kepada manusia yang mengalami masalah dalam hidup

\footnotetext{
${ }^{8}$ Hamdani Bakhran dan Adz Dzaky. 2001. Konseling dan Psikoterapi Islam: Pendekatan Metode Sufistik. Yogyakarta: Fajar Pustaka

${ }^{9}$ Tohirin, 2009. Bimbingan Konseling di Sekolah dan Madrasah Berbasis Integral. Jakarta: Raja Grafindo Persada
} 
keberagamaannya, ingin mengembangkan dimensi dan potensi keberagamaannya seoptimal mungkin, baik secara individu maupun kelompok, agar menjadi manusia yang mandiri dan dewasa dalam beragama, dalam bidang bimbingan akidah, ibadah, akhlak, dan muamalah, melalui berbagai jenis layanan dan kegiatan pendukung berdasarkan keimanan dan ketaqwaan yang terdapat dalam al-Qur'an dan Hadis.

3) Ngalimun mengartikan bahwa bimbingan dan konseling Islam adalah proses pemberian bantuan terhadap individu agar mampu hidup selaras dengan ketentuan dan petunjuk Allah SWT, sehingga dapat mencapai kebahagiaan hidup di dunia dan di akhirat. ${ }^{10}$

Adapun ciri khas konseling Islam yang paling mendasar dan menjadi inti strategi bimbingan konseling Islam menurut Hamdani Bakran Adz-Dzaky, adalah; ${ }^{11}$

1) Berparadigma pada wahyu dan keteladanan para Nabi, Rasulullah SAW dan para sahabat.

2) Konselor berkewajiban memberikan konseling kepada klien dan klien juga diharuskan untuk berikhtiar dengan meminta bimbingan kepada konselor merupakan bagian dari ibadah.

3) Konselor berlaku cermat dan bertanggung jawab, tidak menyimpang dari wahyu karena akan berakibat fatal baik bagi diri sendiri maupun bagi kliennya.

4) System konseling Islam dimulai dari mengarahkan kepada kesadaran nurani denganmembaca ayat-ayat Allah SWT baik ayat-ayat Qauliah maupun ayat-ayat Kauniah.

5) Konselor sejati adalah mereka yang melakukan proses konseling selalu di bawah bimbingan Allah SWT dan Rasul-Nya melalui al-Qur'an dan al-Sunnah.

Dari beberapa pendapat di atas, dapat disimpulkan bahwa bimbingan dan konseling Islam merupakan suatu usaha yang dilakukan dalam rangka mengembangkan potensi dan memecahkan masalah yang dialami klien agar dapat mencapai kebahagiaan hidup di dunia dan di akhirat berdasarkan ajaran Islam.

Ada jiwa yang menjadi fasik dan ada pula jiwa yang menjadi takwa, tergantung kepada manusia yang memilikinya.

Maka Allah mengilhamkan kepada jiwa itu (jalan) kefasikan dan ketakwaannya (8). Sesungguhnya beruntunglah orang yang mensucikan jiwa itu (9). Dan Sesungguhnya merugilah orang yang mengotorinya (10). (Q.S. al-Syams: 8-10)

Ayat ini menunjukan agar manusia selalu mendidik diri sendiri maupun orang lain, dengan kata lain membimbing ke arah mana seseorang itu akan menjadi, baik atau buruk. Proses pendidikan dan pengajaran agama tersebut dapat dikatakan sebagai "bimbingan" dalam bahasa psikologi. Nabi Muhammad SAW, menyuruh manusia muslim untuk menyebarkan atau menyampaikan ajaran Agama Islam yang

\footnotetext{
${ }^{10}$ Ngalimun. 2013. Pelaksanaan Layanan Bimbingan Konseling di SD/MI. Yogyakarta: Deppublish

${ }^{11}$ Hamdani Bakhran dan Adz Dzaky. 2001. Konseling dan Psikoterapi Islam: Pendekatan Metode Sufistik. Yogyakarta: Fajar Pustaka
} 
diketahuinya, walaupun satu ayat saja yang dipahaminya. Dengan demikian dapat dikatakan bahwa nasihat agama merupakan bimbingan (guidance) dalam pandangan psikologi.

Dalam hal ini Islam memberi perhatian pada proses bimbingan. Allah SWT menunjukan adanya bimbingan, nasihat atau petunjuk bagi manusia yang beriman dalam melakukan perbuatan terpuji, seperti yang tertuang pada ayat-ayat yang artinya:

"Sesungguhnya kami telah menciptakan manusia dalam keadaan sebaik-baiknya, kemudian kami kembalikan dia ke tempat yang serendah-rendahnya, kecuali orang-orang yang beriman dan mengerjakan amal soleh, maka bagi mereka pahala yang tidak putus-putusnya" (At-Tiin: 4-5)

"Serulah (manusia) kepada jalan Tuhanmu dengan hikmah dan pelajaran yang baik dan bantahlah mereka dengan cara yang baik. Sesungguhnya Tuhanmu Dialah yang lebih mengetahui tentang siapa yang tersesat dari jalann-Nya dan Dialah yang lebih mengetahui orang-orang yang mendapat petunjuk". (An Nahl:125)

Peranan agama dalam bidang bimbingan dan konseling akan memberikan warna, arah dan susunan hubungan yang tercipta antara klien dan konselor. Prayitno menyatakan unsur-unsur agama tidak boleh diabaikan dalam konseling, dan justru harus dimanfaatkan sebesar-besarnya untuk mencapai kesuksesan, upaya bimbingan dan konseling yaitu kebahagiaan klien.

Alasan yang paling utama dan mendasar dalam menghadirkan bimbingan dan konseling Islam adalah karena Islam mempunyai pandangan-pandangan tersendiri mengenai manusia. Al-Qur'an sumber utama agama Islam, adalah kitab petunjuk, di dalamnya terdapat banyak petunjuk mengenai manusia. Allah SWT, sebagai pencipta manusia, tentu mengetahui secara nyata dan pasti siapa manusia. Melalui Al-Qur'an, Allah SWT memberikan rahasia-rahasia tentang manusia. Oleh karenanya jika ingin mengetahui bagaimana cara menghadapi manusia secara sungguh-sungguh, maka AlQur'an (wahyu) adalah sumber yang layak dijadikan acuan utama. ${ }^{12}$

Ajaran Islam menjadi acuan sebagai landasan yang ideal dalam menjalani kehidupan. Untuk itu tepatlah kiranya jika teori-teori dan teknik-teknik bimbingan dan konseling yang lahir di Barat, terlebih dahulu "diislamkan" sebelum diterapkan dalam kehidupan. Bimbingan dan konseling Islam memberikan jalan mencegah dan memecahkan masalah, mengubah orientasi pribadi, penguatan mental spiritual, penguatan tingkah laku kepada akhlak yang mulia, upaya perbaikan serta teknikteknik bimbingan dan konseling lainnya.

Perbedaan bimbingan dan konseling umum dengan bimbingan dan konseling Islam menurut Ngalimun, di antaranya: ${ }^{13}$

1) Pada umumnya di barat proses layanan bimbingan dan konseling tidak dihubungkan dengan Tuhan maupun ajaran agama. Maka layanan bimbingan dan konseling dianggap sebagai hal yang semata-mata masalah duniawi, sedangkan Islam menganjurkan aktifitas layanan bimbingan dan konseling itu merupakan

\footnotetext{
${ }^{12}$ Ainur Rahim Faqih. Bimbingan Konseling Islam. Yogyakarta: UII Press

${ }^{13}$ Ngalimun. 2013. Pelaksanaan Bimbingan Konseling di SD/MI. Yogyakarta: Deepublish
} 
suatu ibadah kepada Allah SWT suatu bantuan kepada orang lain, termasuk layanan bimbingan dan konseling.

2) Pada umumnya konsep layanan bimbingan dan konseling barat hanyalah didasarkan atas pikiran manusia. Semua teori bimbingan dan konseling yang ada hanyalah didasarkan atas pengalaman-pengalaman masa lalu, sedangkan konsep bimbingan dan konseling Islam didasarkan kepadaAl-Qur'an dan Sunnah Rasul, aktivitas akal dan pengalaman manusia.

3) Konsep layanan bimbingan dan konseling Barat tidak membahas masalah kehidupan sesudah mati. Sedangkan konsep layanan bimbingan dan konseling Islam meyakini adanya kehidupan sesudah mati

4) Konsep layanan bimbingan dan konseling Barat tidak membahas dan mengaitkan diri dengan pahala dan dosa. Sedangkan menurut bimbingan dan konseling Islam membahas pahala dan dosa yang telah dikerjakan.

\section{b. Pendekatan Islam dalam Pelaksanaan Bimbingan Konseling}

Pendekatan Islam dapat dikaitkan dengan aspek-aspek psikologis dalam pelaksanaan bimbingan konseling yang meliputi pribadi, sikap, kecerdasan, perasaan, dan seterusnya yang berkaitan dengan konseli dan konselor. Bagi pribadi muslim yang berpijak pada pondasi tauhid pastilah seorang pekerja keras, namun nilai bekerja baginya adalah untuk melaksanakan tugas suci yang telah Allah berikan dan percayakan kepadanya, ini baginya adalah ibadah. Sehingga pada pelaksanaan bimbingan konseling, pribadi muslim tersebut memiliki ketangguhan pribadi tentunya dengan prinsip-prinsip sebagai berikut: ${ }^{14}$

1) Memiliki Prinsip Dasar yang menjadi landasan hidup yaitu hanya beriman kepada Allah SWT.

2) Memiliki Prinsip Kepercayaan, yaitu beriman kepada Malaikat.

3) Memiliki Prinsip Kepemimpinan, yaitu merujuk kepada kepemimpinan Rasulullah SAW.

4) Memiliki Prinsip Pembelajaran, yaitu berprinsip kepada Al-Qur'an Al Karim.

5) Memiliki Prinsip Masa Depan, yaitu beriman kepada "masa depan" yang hakiki, yaitu Hari Kemudian

6) Memiliki Prinsip Keteraturan, yaitu beriman kepada "Ketentuan Allah"

Jika konselor memiliki prinsip tersebut (Rukun Iman) maka pelaksanaan bimbingan dan konseling tentu akan mengarahkan konseli ke arah kebenaran, selanjutnya dalam pelaksanaannya pembimbing dan konselor perlu memiliki tiga langkah untuk menuju pada kesuksesan bimbingan dan konseling. Pertama, memiliki mission statement yang jelas yaitu "Dua Kalimat Syahadat", kedua, memiliki sebuah metode pembangunan karakter sekaligus simbol kehidupan yaitu "Shalat lima waktu", dan ketiga, memiliki kemampuan pengendalian diri yang dilatih dan disimbolkan dengan "Puasa". Prinsip dan langkah tersebut penting bagi pembimbing dan konselor muslim, karena akan menghasilkan kecerdasan emosi dan spiritual (ESQ) tinggi yang terwujud dalam

\footnotetext{
${ }^{14}$ Tohari, Musnawar. 2010. Dasar-dasar Konseptual Bimbingan Konseling Islam. Yogyakarta: UII Press
} 
Akhlak al-Karimah. Dengan mengamalkan hal tersebut akan memberi keyakinan dan kepercayaan bagi konseli yang melakukan bimbingan dan konseling.

Fiman Allah SWT dalam al-Qur'an yang artinya;

"Dan hendaklah ada diantara kamu suatu umat yang menyeru berbuat kebaikan, dan menyuruh orang melakukan yang benar, serta melarang yang mungkar. Merekalah orang yang mencapai kejayaan." (Ali Imran : 104)

Pada ayat tersebut memberi kejelasan bahwa pelaksanaan bimbingan dan konseling akan mengarahkan seseorang pada kesuksesan dan kebahagiaan, dan bagi konselor sendiri akan mendapat nilai tersendiri dari Allah SWT. Para pembimbing dan konselor perlu mengetahui pandangan filsafat Ketuhanan, manusia disebut mahluk yang berketuhanan, berarti manusia dalam sepanjang sejarahnya senantiasa memiliki kepercayaan terhadap Tuhan atau hal-hal gaib yang menggetarkan hatinya atau hal-hal gaib yang mempunyai daya tarik kepadanya (mysterium trimendum atau mysterium fascinans). Hal demikian oleh agama-agama besar di dunia dipertegas bahwa manusia adalah mahluk yang disebut mahluk beragama (homo religious), oleh karena itu memiliki naluri agama (religious instink), sesuai dengan firman Allah SWT :

"Maka hadapkanlah wajahmu kepada agama Allah (tetaplah atas) fitrah (naluri) Allah yang telah menciptakan manusia menurut naluri itu, tidak ada perubahan pada naluri dari Allah itu. Itulah agama yang lurus, akan tetapi kebanyakan manusia tidak mengetahuinya." (Ar-Rum : 30)

Pada diri konseli juga ada benih-benih agama, sehingga untuk mengatasi masalah dapat dikaitkan dengan agama, dengan demikian konselor dapat mengarahkan individu (counselee) ke arah agamanya, dalam hal ini Agama Islam. Dengan berkembangnya ilmu jiwa, diketahui bahwa manusia memerlukan bantuan untuk mengatasi kesulitan yang dihadapinya dan muncullah berbagai bentuk pelayanan kejiwaaan, dari yang paling ringan (bimbingan), yang sedang (konseling) dan yang paling berat (terapi), sehingga berkembanglah psikologi yang memiliki cabang-cabang terapan, diantaranya bimbingan, konseling dan terapi.

Selanjutnya ditemukan bahwa agama, terutama Agama Islam mempunyai fungsifungsi pelayanan bimbingan, konseling dan terapi di mana filosofinya didasarkan atas ayat-ayat Al-Qur'an dan Sunnah Rosulullah SAW. Proses pelaksanaan bimbingan, konseling dan psikoterapi dalam Islam, tentunya membawa kepada peningkatan iman, ibadah dan jalan hidup yang diridlai Allah SWT.

\section{c. Tujuan Bimbingan dan Konseling Islam}

Thohari Musnamar membagi tujuan bimbingan dan konseling Islam menjadi tujuan umum dan tujuan khusus. Adapun tujuan umum dari bimbingan dan konseling Islam adalah membantu individu mewujudkan dirinya menjadi manusia seutuhnya agar mencapai kebahagiaan hidup di dunia dan di akhirat. Tujuan bimbingan konseling Islam adalah; (a) Membantu individu agar tidak menghadapi masalah; (b) Membantu individu mengatasi masalah yang dihadapi; (c) Membantu individu memelihara dan mengembangkan situasi dan kondisi yang baik atau yang telah baik agar tetap baik 
atau menjadi lebih baik, sehingga tidak akan menjadi sumber masalah bagi dirinya dan orang lain. $^{15}$

Adapun tujuan konseling Islam menurut Hamdani Bakran Adz-Dzaky, adalah: ${ }^{16}$

1) Untuk menghasilkan suatu perubahan, perbaikan, kesehatan, dan kebersihan jiwa dan mental. Jiwa menjadi tenang dan damai (muthmainah), bersikap lapang dada (radhiyah) dan mendapatkan pencerahan taufik dan hidayah Tuhannya (mardhiyah).

2) Untuk menghasilkan suatu perubahan, perbaikan dan kesopanan, tingkah laku yang dapat memberikan manfaat baik pada diri sendiri, lingkungan keluarga, lingkungan kerja, maupun lingkungan social dan alam sekitarnya.

3) Untuk menghasilkan kecerdasan rasa (emosi) pada individu sehingga muncul dan berkembang rasa toleransi, tolong-menolong, kesetiakawanan dan rasa kasih sayang.

4) Untuk menghasilkan kecerdasan spiritual pada diri individu sehingga muncul dan berkembang rasa keinginan untuk berbuat taat kepada Tuhannya, ketulusan mematuhi segala perintah-Nya, serta ketabahan untuk menerima ujian-Nya.

5) Untuk menghasilkan potensi ilahiyyah, sehingga dengan potensi itu individu dapat melakukan tugasnya sebagai khalifah dengan baik, menanggulangi berbagai persoalan hidup dan dapat memberikan kemanfaatan dan keselamatan bagi lingkungan pada berbagai aspek kehidupan.

\section{d. Fungsi Bimbingan dan Konseling Islam.}

Fungsi bimbingan dan konseling Islam dapat dirumuskan sebagai berikut:

1) Fungsi preventif, yakni membantu individu menjaga atau mencegah timbulnya masalah bagi dirinya

2) Fungsi kuratif atau korektif, membantu individu memecahkan masalah yang sedang di hadapi atau di alami

3) Fungsi preventif, yakni membantu individu menjaga agar situasi atau kondisi yang semula tidak baik telah menjadi baik (terpecahkan ) itu kembali menjadi tidak baik (menimbulkan masalah kembali)

4) Fungsi developmental atau pengembangan, yakni membantu individu memelihara dan mengembangkan situasi dan kondisi yang telah baik agar tetap baik dan menjadi lebih baik, sehingga tidak memungkinkan menjadi sebab munculnya masalah baginya.

5) Fungsi Advokasi, yakni pemberian bantuan berupa perlindungan, pengayoman, dan pendampingan hukum ketika klien terjerat masalah yang berkaitan dengan hukum.

Berdasarkan fungsi bimbingan dan konseling Islam di atas, terlihat bahwa substansi layanan tersebut adalah untuk memecahkan setiap persoalan yang dihadapi oleh peserta didik terutama pada masa remaja dalam kehidupan sehari-hari serta mengusahakan sedapat mungkin agar masalah yang sama tidak terulang lagi. Fungsi konseling secara tradisional digolongkan kepada tiga fungsi, yakni; (a) Remedial atau

${ }^{15}$ Tohari, Musnawar. 2010. Dasar-dasar Konseptual Bimbingan Konseling Islam. Yogyakarta: UII Press

${ }^{16}$ Hamdani Bakhran dan Adz Dzaky. 2001. Konseling dan Psikoterapi Islam: Pendekatan Metode Sufistik. Yogyakarta: Fajar Pustaka 
rehabilitative. Secara historis konseling lebih banyak memberikan penekanan pada fungsi remedial karena sangat dipengaruhi oleh psikologi klinik dan psikiatri. Peranan remedial berfokus pada masalah: penyesuaian diri, menyembuhkan masalah psikologis yang dihadapi, mengembalikan kesehatan mental dan mengatasi gangguan emosional; (b) Fungsi educative/pengembangan. ${ }^{17}$ Fungsi ini berfokus kepada masalah: membantu meningkatkan keterampilan-keterampilan dalam kehidupan, mengidentifikasi dan memecahkan masalah-masalah hidup, membantu meningkat kemampuan menghadapi transisi dalam kehidupan, untuk keperluan jangka pendek, konseling membantu individu menjelaskan nilai-nilai, menjadi lebih tegas, mengendalikan kecemasan, meningkatkan keterampilan komunikasi antar pribadi, memutuskan arah hidup, menghadapi kesepian dan sebagainya; (c) Fungsi preventif/pencegahan. Fungsi ini membantu individu agar dapat berupaya aktif untuk melakukan pencegahan sebelum mengalami masalah-masalah kejiwaan karena kurangnya perhatian. Upaya preventif meliputi pengembangan strategi-strategi dan program-program yang dapat digunakan untuk mencoba mengantisipasi dan mengelakkan resiko-resiko hidup yang tidak perlu terjadi.

\section{e. Jenis-Jenis Pelayanan Bimbingan dan Konseling Islam}

Berbagai jenis layanan perlu dilakukan sebagai wujud nyata penyelenggaraan pelayanan bimbingan dan konseling terhadap sasaran layanan, yaitu peserta didik (klien). Suatu kegiatan dalam bimbingan dan konseling disebut layanan apabila kegiatan tersebut dilakukan melalui kontak langsung dengan sasaran layanan (klien) dan secara langsung berkenaan dengan permasalahan ataupun kepentingan tertentu yang dirasakan oleh sasaran layanan itu. Serta dampak positif layanan yang dimaksudkan diharapkan dapat secara langsung dirasakan oleh sasaran yang mendapatkan layanan tersebut.

Dalam hal ini tujuh jenis layanan agama menjadi jenis-jenis pelayanan bimbingan dan konseling Islam, yaitu layanan orientasi agama, layanan informasi agama, layanan penempatan dan penyaluran bakat keberagamaan, layanan bimbingan pembelajaran/pengajian agama, layanan konseling agama perorangan, layanan bimbingan agama kelompok, dan layanan konseling agama. Jenis layanan bimbingan dan konseling Islam dapat dijelaskan sebagai berikut: ${ }^{18}$

1) Layanan Orientasi Agama; Layanan yang memungkinkan umat mengenal dan memahami lingkungan keberagamaannya dari orang-orang yang dapat memberikan pengaruh agama untuk mempermudah orang berperan dilingkungan hidup keberagamaan yang baru dimasukinya. Misalnya orang yang akan masuk Islam. Sebelum mengucapkan dua kalimat syahadat, adalah sangat hikmat dan bijaksana, kalau diperkenalkan lebih dahulu makna dan hakikatnya dua kalimat syahadat yang diucapkan itu. Dengan cara demikian diharapkan orang terjauh dari sifat keterpaksaan dalam menganut agama, dengan demikian orang mudah menyesuaikan diri dengan lingkungan keberagamaannya. Dan menjadikan agama

\footnotetext{
${ }^{17}$ Ngalimun. 2014. Bimbingan Konseling di SD/MI Suatu Pendekatan Proses. Yogyakarta: Aswaja Pressindo

${ }^{18}$ Ngalimun. 2013. Pelaksanaan Layanan Bimbingan Konseling di SD/MI. Yogyakarta: Deepublish 
sebagai kebutuhan jiwa dan sumber kebahagiaan hidup. Disamping materi akidah yang dapat di angkat melalui orientasi agama, materi ibadah, akhlak dan muamalah bisa pula di angkat.

2) Layanan Informasi Agama. Jenis layanan yang memungkinkan umat atau orang yang beragama menerima dan memahami informasi keberagamaannya dari sumber yang layak dipercaya untuk dapat digunakan sebagai bahan pertimbangan dalam melakukan amal-amal keagamaan dalam mengambil keputusan dan pertimbangan bagi penentuan sikap dan tingkah laku keberagamaan. Layanan informasi agama bertujuan membekali umat dengan berbagai hal yang sangat berguna bagi kehidupan ini.

3) Layanan Penempatan dan Penyaluran Bakat Keberagamaan. Layanan yang memungkinkan umat beragama memperoleh penempatan dan penyaluran yang tepat dan benar dalam pengembangan hidup keberagamaan sesuai dengan potensi, minat, bakat, situasi, dan kondisi pribadi manusia beragama yang bersangkutan.

4) Layanan Bimbingan Agama. Layanan yang memungkinkan orang beragama mengembangkan sikap dan kebiasaan belajar agama yang baik, materi pengajian agama yang cocok dengan kecepatan dan kesulitan belajar agama, serta berbagai aspek tujuan dan kegiatan belajar agama lainnya yang berguna bagi kehidupan keberagamaan.

5) Layanan Konseling Agama Perorangan. Layanan yang memungkinkan orang beragama mendapatkan layanan langsung tatap muka dengan konselor agama dalam rangka pengentasan permasalahan agama yang dihadapi klien. Permasalahan keberagamaan yang dapat dilayani melalui konseling agama perorangan ini meliputi semua aspek keagamaan. Konselor agama melayani klien secara individual.

6) Layanan Bimbingan Agama Kelompok. Layanan yang memungkinkan sejumlah (sekelompok) orang yang beragama memperoleh kesempatan bagi pembahasan dan pengentasan masalah keberagamaan yang mereka alami masing-masing melalui suasana dan dinamika kelompok.

7) Layanan Konseling Agama Kelompok. Layanan yang dimaksudkan untuk memungkinkan sejumlah orang yang beragama secara berjamaah memperoleh bahan dan informasi dari nara sumber tertentu tentang masalah hidup keberagamaan mereka yang dapat dijadikan bahan pertimbangan dalam menentukan sikap dan tingkah laku keberagamaan.

Untuk memperkaya wawasan tentang jenis layanan bimbingan dan konseling Islam ini, di antara jenis-jenis layanan bimbingan dan konseling di sekolah yang bersumber dari buku-buku umum, yaitu dalam buku "Seri Pemandu" (Pelaksanaan Bimbingan dan Konseling di Sekolah) Buku I karangan Prayitno, dkk., di antara layanan itu adalah; ${ }^{19}$

1) Layanan orientasi. Layanan bimbingan dan konseling yang memungkinkan peserta didik (klien) memahami lingkungan yang baru dimasuki peserta didik, untuk

\footnotetext{
${ }^{19}$ Prayitno dan Arman Amti. 1999. Dasar-dasar Bimbingan Konseling. Jakarta: Renika Cipta
} 
mempermudah dan memperlancar berperannya peserta didik di lingkungan yang baru itu.

2) Layanan informasi. Layanan bimbingan dan konseling yang memungkinkan peserta didik (klien) menerima dan memahami berbagai informasi yang dapat dipergunakan sebagai bahan pertimbangan dan pengambilan keputusan untuk kepentingan peserta didik.

3) Layanan penempatan dan penyaluran. Layanan bimbingan dan konseling yang memungkinkan peserta didik memperoleh penempatan dan penyaluran yang tepat, sesuai dengan potensi, bakat dan minat, serta kondisi pribadinya

4) Layanan pembelajaran. Layanan bimbingan dan konseling yang memungkinkan peserta didik mengembangkan diri berkenaan dengan sikap dan kebiasaan belajar yang baik, materi belajar yang cocok dengan kecepatan dan kesulitan belajarnya, serta berbagai aspek tujuan dan kegiatan belajar lainnya.

5) Layanan konseling perorangan. Layanan bimbingan dan konseling yang memungkinkan peserta didik mendapatlan layanan langsung tatap muka (secara perorangan) dengan guru pembimbing dalam rangka pembahasan dan pengentasan permasalahan pribadi yang dideritanya.

6) Layanan bimbingan kelompok. Layanan bimbingan dan konseling yang memungkinkan sejumlah peserta didik secara bersama-sama melalui dinamika kelompok memperoleh berbagai bahan dari nara sumber tertentu (terutama guru pembimbing) membahas secara bersama-sama pokok bahasan (topik) tertentu yang berguna untuk menunjang pemahaman dan kehidupannya sehari-hari dan/atau untuk perkembangan dirinya baik sebagai individu maupun sebagai pelajar, dan untuk pertimbangan dalam pengambilan keputusan dan/atau tindakan tertentu.

7) Layanan konseling kelompok. Layanan bimbingan dan konseling yang memungkinkan peserta didik memperoleh kesempatan untuk pembahasan dan pengentasan permasalahan yang dialaminya melalui dinamika kelompok; masalah yang dibahas itu adalah masalah-masalah pribadi yang dialami oleh masing-masing anggota kelompok.

Selanjutnya yang berkaitan dengan perkembangan konseling, khusus konseling sekolah adalah adanya kebutuhan nyata dan kebutuhan potensial para siswa pada beberapa jenjang pendidikan, yaitu meliputi beberapa tipe konseling berikut ini:

1) Konseling krisis, dalam menghadapi saat-saat krisis yang dapat terjadi misalnya akibat kegagalan sekolah, kegagalan pergaulan atau pacaran, dan penyalahgunaan zat adiktif.

2) Konseling fasilitatif, dalam menghadapi kesulitan dan kemungkinan kesulitan pemahaman diri dan lingkungan untuk arah diri dan pengambilan keputusan dalam karir, akademik, dan pergaulan social.

3) Konseling preventif, dalam mencegah sedapat mungkin kesulitan yang dapat dihadapi dalam pergaulan atau sexual, pilihan karir, dan sebagainya.

4) Konseling developmental, dalam menopang kelancaran perkembangan individual siswa seperti pengembangan kemandirian, percaya diri, citra diri, perkembangan karir dan perkembangan akademik. 
Dengan demikian, kebutuhan akan hubungan bantuan, terutama konseling, pada dasarnya timbul dari diri dan luar individu yang melahirkan seperangkat pertanyaan mengenai apakah yang harus diperbuat individu. Dalam konsep Islam, pengembangan diri merupakan sikap dan perilaku yang sangat diistimewakan. Manusia dituntut untuk mampu mengoptimalkan potensi dirinya, sehingga menjadi pakar dalam disiplin ilmu pengetahuan dan menjadikannya berkedudukan yang mulia di sisi Allah SWT.

\section{Perluasan Setting Bimbingan Konseling}

Ruang lingkup/daerah kerja bimbingan dan konseling di manapun, baik di sekolah, luar sekolah maupun di masyarakat luas, maka bidang pelayanan bimbingan dan konseling harus mencakup kelima bidang pelayanan, yaitu; bidang bimbingan pribadi, bidang bimbingan pembelajaran, bimbingan sosial, bimbingan karir dan bimbingan keluarga.

Bimbingan social adalah bimbingan dan konseling yang membantu individu dalam mengenal lingkungan dan mengembangkan diri dalam hubungan social yang dilandasi budi pekerti luhur, serta tanggung jawab kemasyarakatan dan kenegaraan. Bimbingan belajar adalah bidang pelayanan bimbingan dan konseling untuk membantu individu dalam mengembangkan diri, sikap dan kebiasaan belajar yang baik untuk menguasai pengetahuan dan keterampilan serta menyiapkannya untuk pendidikan yang lebih tinggi.

Bimbingan karier adalah pelayanan bimbingan dan konseling untuk membantu siswa dalam perencanaan, pengembangan masa depan, dan kemampuan karier.

Bimbingan keluarga adalah pelayanan bimbingan terhadap keluarga sebagai bagian dari mata rantai pendidikan. Penelitian membuktikan bahwa jika keluarga bermasalah, maka sedikit banyak akan berpengaruh tarhadap anak.

Dalam menentukan bidang-bidang pelayanan bimbingan dan konseling ini mengikuti dimensi yang ada pada manusia sebagai makhluk multidimensi, maka bidang pelayanan bimbingan dan konseling Islam bisa pula dikembangkan. Jika manusia multidimensi tersebut adalah makhluk jasmani, rohani, beragama, berakhlak, social, berakal dan estetika, tentu ada pula bidang bimbingan jasmani, bimbingan agama, bimbingan estetika, bimbingan pengembangan akal. Khusus tentang dimensi agama, karena agama sangat berpengaruh dalam segala aspek dan aktivitas kehidupan manusia, maka bidang bimbingan agama sangat wajar dijadikan salah satu bidang dalam bimbingan dan konseling. Bimbingan dan konseling agama sebagai salah satu bidang atau disiplin ilmu bimbingan dan konseling, substansi keduanya tidaklah jauh berbeda pengertiannya, perbedaannya hanya terletak pada isi dan pendekatan. Pada substansinya, baik bimbingan dan konseling agama maupun bimbingan dan konseling umum adalah pelayanan bantuan kemanusiaan atau pemberian nasehat dalam makna luas dalam bahasa agama kepada manusia, baik secara individu atau kelompok. Sedangkan pada esensi utamanya adalah usaha untuk memanusiakan manusia, amar makruf dan nahi mungkar. $^{20}$

${ }^{20}$ Syamsu Yusuf dan Juntika Nurikhsan. 2008. Landasan Bimbingan dan Konseling. Bandung Remaja Rosdakarya 


\section{KESIMPULAN}

Bimbingan konseling adalah proses pemberian bantuan yang dilakukan melalui wawancara konseling (face to face) oleh seorang ahli (konselor) kepada individu yang sedang mengalami sesuatu masalah (konseli) yang bermuara pada teratasinya masalah yang dihadapi konseli serta dapat memanfaatkan berbagai potensi yang dimiliki dan sarana yang ada, sehingga individu atau kelompok individu itu dapat memahami dirinya sendiri untuk mencapai perkembangan yang optimal, mandiri serta dapat merencanakan masa depan yang lebih baik untuk mencapai kesejahteraan dan kebahagiaan hidup.

Bimbingan dan konseling Islam adalah karena Islam mempunyai pandanganpandangan tersendiri mengenai manusia. Al-Qur'an sumber utama agama Islam, adalah kitab petunjuk, di dalamnya terdapat banyak petunjuk mengenai manusia. Allah SWT, sebagai pencipta manusia, tentu mengetahui secara nyata dan pasti siapa manusia. Melalui Al-Qur'an, Allah SWT memberikan rahasia-rahasia tentang manusia. Oleh karenanya jika ingin mengetahui bagaimana cara menghadapi manusia secara sungguh-sungguh, maka Al-Qur'an (wahyu) adalah sumber yang layak dijadikan acuan utama.

\section{DAFTAR PUSTAKA}

Abdurrachman dan Sudjadi, Pendidikan Luar Biasa Umum. Jakarta: Departemen Pendidikan dan Kebudayaan, 1995

Adz-Dzaky, Hamdani Bakran, Konseling dan Psikoterapi Islam, Penerapan Metode Sufistik, Yogyakarta: Fajar Pustaka Baru, 2001.

Amin, Samsul Munir, Bimbingan dan Konseling Islam, Jakarta: Amzah, 2010.

Amin, Samsul Munir, Bimbingan Konseling Islam, Jakarta: Amzah, 2010

Daud, Wan Mohd Nor Wan, Filsafat dan Praktik Pendidikan Islam, Bandung: Mizan, 1998

Faqih, Ainur Rahim, Bimbingan dan Konseling Dalam Islam, Yogyakarta: UII Press, 2001.

Hallen, Bimbingan dan Konseling, Jakarta: Quantum Teaching, 2005.

Hasyim, Farid, dan Mulyono, Bimbingan dan Konseling Religius, Yogyakarta: Ar-Ruz Media, 2010.

Hayat, Abdul, Konsep-konsep Konseling Berdasarkan Ayat-ayat Al-Qur'an, Banjarmasin: Antasari Press, 2008.

Lubis, Saiful Akhyar, Konseling Islami: Kyai Dan Pesantren, Yogyakarta: Elsak Press, 2007.

Muhyiddin, Muhammad, Manajemen ESQ Power, Yogyakarta: Diva Pres, 2007.

Munir, A Samsul, Bimbingan dan Konseling Islam, Jakarta: Amzah, 2010.

Musnawar, Thohari, Dasar-dasar Konseptual Bimbingan Konseling Islam, Yogyakarta: UII Press, t.th.

Ngalimun. Pelaksanaan Layanan Bimbingan Konseling di SD/MI. Yogyakarta: Deepublish, 2013.

Prayitno dan Emran Amti, Dasar-Dasar Bimbingan Dan Konseling, Jakarta: Rineka Cipta, 1999

Tohirin, Bimbingan Konseling Di Sekolah Dan Madrasah, Berbasis Integral, Jakarta: Raja Grafindo Persada, 2009.

Walgito, Bimo, Bimbingan dan Konseling (Studi dan Karir), Yogyakarta: Andi, 2005.

Wingkel, Bimbingan Dan Konseling Di Sekolah, Jakarta : Gramedia, 1987. 